\title{
Oral-Facial-Digital Syndrome 1 Protein
}

National Cancer Institute

\section{Source}

National Cancer Institute. Oral-Facial-Digital Syndrome 1 Protein. NCI Thesaurus. Code C75881.

Oral-facial-digital syndrome 1 protein (1012 aa, 117 kDa) is encoded by the human OFD1 gene. This protein may play a role in development. 